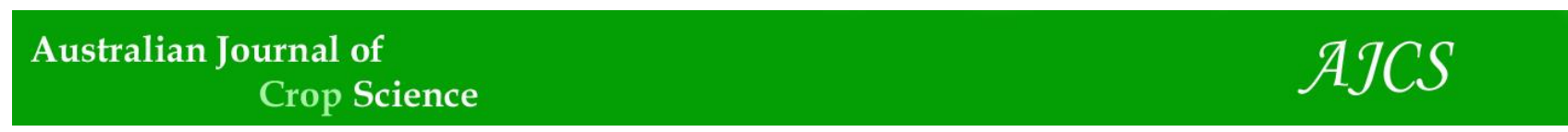

AJCS 12(02):326-334 (2018)

ISSN:1835-2707

doi: 10.21475/ajcs.18.12.02.pne1070

\title{
Genetic resistance of local upland rice populations from East and North Kalimantan, Indonesia against some important diseases
}

\author{
Nurhasanah ${ }^{*}$, Kadis Mujiono, Efri Surya Darma, Widi Sunaryo \\ Department of Agroecotechnology, Faculty of Agriculture, Mulawarman University. Jl. Pasir Balengkong No.1 \\ Kampus Gunung Kelua, Samarinda, East Kalimantan-Indonesia 75119, Tel./Fax. +62-541-749159/738341,
}

\section{*Corresponding author: nurhasanah_2710@yahoo.com}

\begin{abstract}
Plant diseases are major obstacles in achieving optimal yields in crop plants including rice. The use of diseases-resistant varieties is one of the most practical and economical approaches to overcome this problem. The local rice populations (landraces) are important genetic resources containing useful genes for many important traits, including disease resistance characters. The objectives of this study were to evaluate the responses of East and North Kalimantan local upland rice population against rice diseases and to select the local cultivars having resistance against the diseases. Disease resistance was evaluated using natural disease epidemic selection. A 109 Indonesian local upland rice cultivars were grown in two different growing conditions, in screen house and field trial. Diseases were characterized by their symptoms on the plants and the corresponding causing agents. Disease intensity was scored by observing the percentage of disease symptoms on the plants in the field trial. The results showed that bacterial blight (Xanthomonas oryzae) was the most frequent disease infecting East and North Kalimantan local upland rice population followed by narrow brown spot, brown spot, sheath blight and black kernel. A specific interaction between the host and pathogen was observed in this study. Some genotypes were resistant, and some others are susceptible to the particular disease. However, most of the local rice cultivars were grouped into resistant and moderately resistant genotypes. The East and North Kalimantan local upland rice population characterized in this study, contained genes that confer resistance to one or more pathogens, which could be further used as a source of vertical or horizontal resistance genes in rice breeding programs.
\end{abstract}

Keywords: Diversity, East and North Kalimantan, genetic resistance, local rice, rice diseases.

\section{Introduction}

Disease is a biotic environmental stress which can cause significant yield loss or even crop failure in most of the agricultural crops. It is a major constraint limiting the optimal production of crops included rice. Many studies have reported yield loss due to rice diseases in different intensity, from light to very severe yield losses (Sparks et al., 2012; Barnwal et al., 2013; Kihoro et al., 2013). As an example, the estimated annual loss of rice only due to blast disease was enough to feed 60 million people for one year (Pennisi, 2010). Besides the direct negative impact on the global food production in term of quantity reduction of food, diseases also have indirect implications, in term of public health, societies, environments, economic fabrics and farmers, which is always underestimated (Zadoks, 2008; Mills et al., 2011; Savary et al., 2012).

Plant diseases can be caused by diverse pathogens, including viruses, bacteria, fungi, and nematodes. Various symptoms can be observed as the characteristics of the diseases infestation on plants. Each disease causes different severity, but the important plant diseases cause significant reduction in yield and quality of crop production. Several factors could increase the occurrence and severity of diseases including the use of high-yielding variety and intensive agricultural practice (Teng, 1990), besides favorable environment for pathogen development (Anderson et al., 2004; Agrios, 2005; Pautasso et al., 2012).

Several solutions have been implemented to control the damage caused by diseases including cultural practices, the use of resistant variety and physical, biological and chemical control methods. Nevertheless, controlling diseases using chemical fungicide should be placed as the last solution, since it is ecologically unfriendly (Geigera et al., 2010), causing pollution to the environment (Paoletti and Pimentel, 2000), and also harmful to human health (Eskenazi et al., 1999; González-Rodríguez et al., 2008; Hura et al., 2008). Plant diseases management should be more sustainable, less fungicide-dependent, ecologically safe and socially acceptable to ensure global food security and safety.

Among all disease managements, the use of resistant varieties is the most practical and economical approaches. Breeding for disease resistant varieties has been long used for managing the rice diseases which contributed immensely to world's rice productivity. Furthermore, developing resistant varieties is becoming an important agenda, not only due to increase of interest in organic agricultural practices but also 
for the favor of implementing sustainable agriculture based on environmental sustainability.

The existence of resistance genes is the key component in the development of disease resistant varieties. It involves identification, selection, and development of diseaseresistant plant lines carrying candidate genes for both qualitative and quantitative resistance in the germplasms. Rice gene pools from the traditional/local variety are important reservoirs of useful genes for many important traits, including disease resistance characters. The Large variation of agro-morphological traits (Nurhasanah et al., 2016), as well as yield related traits (Nurhasanah et al., 2017) in East and North Kalimantan local upland rice population have been reported earlier. However, their genetic potential against disease has not been characterized. Therefore, identify disease resistance genes in the local rice cultivars is one of important strategy to enrich rice genetic resources for the disease resistance breeding program as reported in this paper. The objectives of this study were to evaluate the response of East and North Kalimantan local rice cultivars against rice diseases and to select the corresponding resistant local upland rice genotypes.

\section{Results}

\section{Diseases identification}

Disease identification could be conducted by observing the symptoms and causing agents. Based on the observation, there were several important rice diseases infested the local rice population, namely bacterial blight (Xanthomonas sp), brown spot (Helminthosporium oryzae), sheath blight (Rhizoctonia solani), narrow brown spot (Cercospora oryzae), and black kernel (Curvularia lunata).

Bacterial blight (Xanthomonas oryzae), the symptoms of bacterial blight were observed from yellowing and drying of leaves (Fig. 1). There was bacterial ooze, thick or turbid liquid, coming out of the cut ends of infected leaves in a transparent glass container with clear water. Xanthomonas sp. was suspected as the causing agent of this disease, originating from a gram-negative bacillus bacterium (Figure 1b). We were not able to further observe and determine the species of the bacteria, Xanthomonas oryzae pv. oryzae a leaf blight causing agent in rice (Oryza sativa) (Swings et al., 1990).

Narrow brown spot (Cercospora oryzae), narrow brown spot disease infection was observed in the presence of symptoms of a narrow elongated form of spots on the leaves. The spots are reddish brown to dark brown, parallel to the midrib. Spotting typically of 2-10 mm was measured with a width of 1-1.5 mm (Fig. 2A-B) (Khush and Virmani, 1985). Observation of fungi that caused the disease showed that the narrow brown spot was caused by infection of the fungus Cercospora oryzae (Fig. 2C-D). The fungi conidia were observed as inverted mushroom-shaped mace and insulated (Fig. 2D).

Brown spot (Helminthosporium oryzae), brown spot disease symptom on the plants was observed as lesions or spots on the leaf surface (Fig. 3A). Firstly, the spots were small, circular, and dark brown to purple-brown. Further, the spots fully developed into light, brown, and oval circle with the center or midpoint of gray color, surrounded by a fringe of reddish brown caused by toxin produced by the fungi (Sunder et al., 2014). Based on the fungi observation, Brown Spot disease is caused by the fungus Helminthosporium oryzae or Drechslera oryzae (Subramanian and Jane, 1966). The characteristics of Helminthosporium oryzae conidia could be clearly observed under a light microscope, which was brown, sectional, cylindrical and slightly curved with a bit wider in the middle part (Fig. 3B).

Sheath blight (Rhizoctonia solani), the symptom of sheath blight disease was observed from aging plant leaves or as dry condition (Fig. 4A-B), then the presence of oval-shaped or greenish gray ellipse on the leaf midrib (Bhaktavatsalam et al., 1978; Prasad and Eizenga, 2008). Observation of sheath blight disease-causing agent indicated that the disease was caused by the fungus Rhizoctonia solani (Fig. 4C-F). The mycelium consisted of insulated hyphae. The hyphae were multinucleate and tended to branch. There was septum near to each hyphae branch and slightly narrowing at the branch.

Black kernel (Curvularia lunata), black kernel disease is characterized by the black kernel produced by the infected grains. The grains (outer lemma and palea) on the infected panicles covered by a dark brown to black soot (Breckenridge and Sangerapillai, 1978; Cabi, 2017) (Fig. 5A). The fungi grew rapidly on PDA media. The colony was brown to black, hairy, like the texture of velvet or wool, and loose. Conidia of the fungus Curvularia lunata had curved shape and consisted of 3 or 4 septa per cell, wherein the first and last cells usually have lighter color (pale brown) than the middle cell (Fig. 5B).

\section{Diseases infection and intensity}

Amongst all rice diseases, bacterial blight was the most frequent disease infecting East and North Kalimantan local upland rice population followed by narrow brown spot, brown spot, sheath blight and black kernel in both of cultivation type (Table 1). Bacterial blight, caused by Xanthomonas sp infected around $45 \%$ and $78 \%$ of the local upland rice cultivars in the screen house and the field trial, respectively. On the other hand, black kernel as the rarest rice disease observed in this study infected only one genotype (Busang, from Kutai Barat) in screen house test, and none of the local rice cultivars were infested by this disease in the field trial. In this study, disease infection was observed more frequently in the field than in screen house for almost all of rice diseases, except for sheath blight.

Parallelisms between the screen house test and field trial were varied among rice diseases. Almost eighty percent of the genotypes attacked by bacterial blight in screen house were also infected by this disease in the field trial (Table 1). On the other hand, the consistency of sheath blight infection in screen house and field trial was very low, in which only fourteen percent of the genotypes having the disease symptoms in screen house was also infected in the field trial. In the field test, we observed the intensity of disease infection in the rice population. Disease intensity was scored based on the percentage of infected leaf area on the plants. The rice disease intensity varied from light to very severe (Table 1). Narrow brown spot disease infected in wide range intensity, in which the maximal intensity could cause plant severity up to $95 \%$, in which the lesions were presented in almost all of the plant. Based on disease intensity/severity scores, the cultivars were grouped into resistant, moderately 
Table 1. Disease observation in East and North Kalimantan local upland rice population.

\begin{tabular}{lllll}
\hline \multirow{2}{*}{ Rice disease } & \multicolumn{2}{c}{ Number of cultivar infected } & $\begin{array}{l}\text { Parallelism } \\
(\%)^{\mathrm{a}}\end{array}$ & $\begin{array}{l}\text { Intensity } \\
(\%)^{\mathrm{b}}\end{array}$ \\
\cline { 2 - 3 } & Screenhouse & Field trial & 79.6 & $2-50$ \\
Bacterial Blight & 49 & 85 & 76.2 & $0.5-95$ \\
Narrow Brown Spot & 21 & 70 & 33.3 & $0.5-70$ \\
Brown Spot & 15 & 35 & 14.3 & $2-15$ \\
Sheath Blight & 14 & 4 & 0 & - \\
Black Kernel & 1 & 0 & 0 & - \\
\hline
\end{tabular}

${ }^{a}$ Parallelism percentage was calculated based on number of cultivars infected in both of cultivation condition, in screen house and field trial; ${ }^{b}$ Disease intensity was scored in the field trial growing condition.

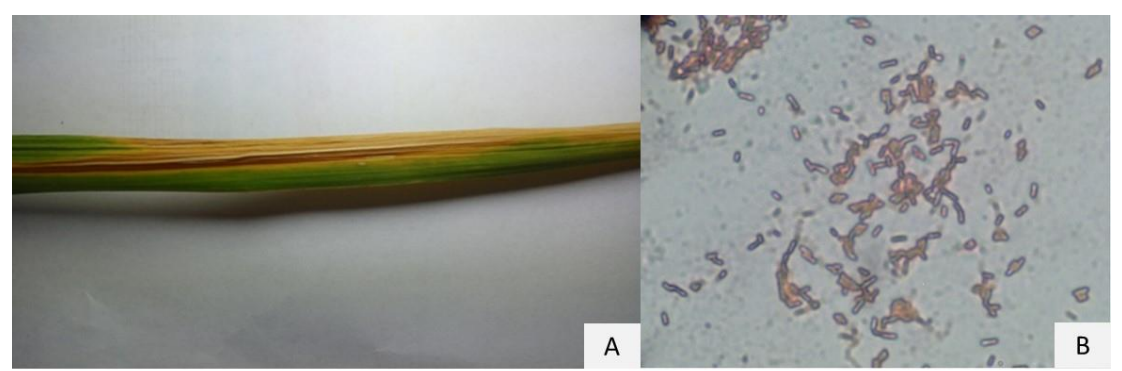

Fig 1. Bacterial Blight in rice population; A. The infected leave; B. Microscopies observation of the bacteria.

Table 2. Disease intensity and disease severity score of East and North Kalimantan local upland rice cultivars on field trial.

\begin{tabular}{lcccccc}
\hline \multirow{2}{*}{ Scale } & \multirow{2}{*}{ Infected leaf area (\%) } & \multicolumn{4}{c}{ Number of cultivars } & Disease severity \\
\cline { 2 - 5 } & & $\mathrm{BB}^{*}$ & NBS & BS & SB & Resistant \\
\hline 0 & 0 & 21 & 37 & 64 & 103 & Resistant \\
1 & $<1$ & 0 & 1 & 2 & 0 & Resistant \\
2 & $1-3$ & 4 & 1 & 9 & 2 & Resistant \\
3 & $4-5$ & 24 & 10 & 12 & 0 & Moderately resistant \\
4 & $6-10$ & 30 & 8 & 10 & 3 & Moderately resistant \\
5 & $11-15$ & 3 & 11 & 4 & 1 & Moderately resistant \\
6 & $16-25$ & 12 & 17 & 5 & 0 & Moderately susceptible \\
7 & $26-50$ & 15 & 19 & 2 & 0 & Susceptible \\
8 & $51-75$ & 0 & 4 & 1 & 0 & Susceptible \\
9 & $76-100$ & 0 & 1 & 0 & 0 & \\
\hline
\end{tabular}

(BB) Bacterial Blight, (NBS) Narrow Brown Spot, (BS) Brown Spot, (SB) Sheath Blight.

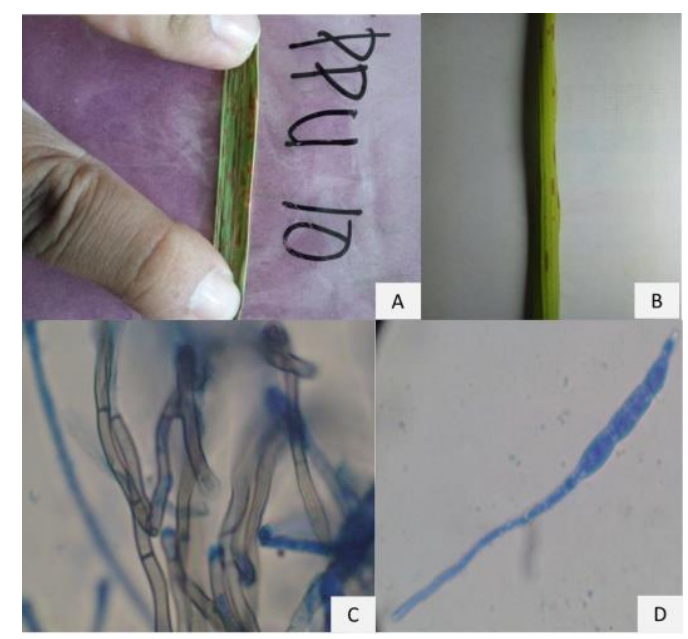

Fig 2. Narrow Brown Spot infection; A-B. The infected leaves; C. Hyfa of Cercospora oryzae dan D. Conidia of Cercospora oryzae. 
Table 3. Diseases susceptibility of East and North Kalimantan local upland rice population.

\begin{tabular}{lcccc}
\hline Disease infection & ${ }^{*}$ & \multicolumn{2}{c}{ Screen house } & \multicolumn{2}{c}{ Field Trial } \\
\cline { 2 - 5 } & $\begin{array}{c}\text { Number of } \\
\text { cultivar }\end{array}$ & $\%$ & $\begin{array}{c}\text { Number of } \\
\text { cultivar }\end{array}$ & $\%$ \\
\hline 4 types & 0 & 0.0 & 3 & 2.8 \\
3 types & 4 & 3.7 & 10 & 9.2 \\
2 types & 22 & 20.2 & 54 & 49.5 \\
1 type & 44 & 40.3 & 42 & 38.5 \\
0 & 39 & 35.8 & 0 & 0.0 \\
\hline
\end{tabular}

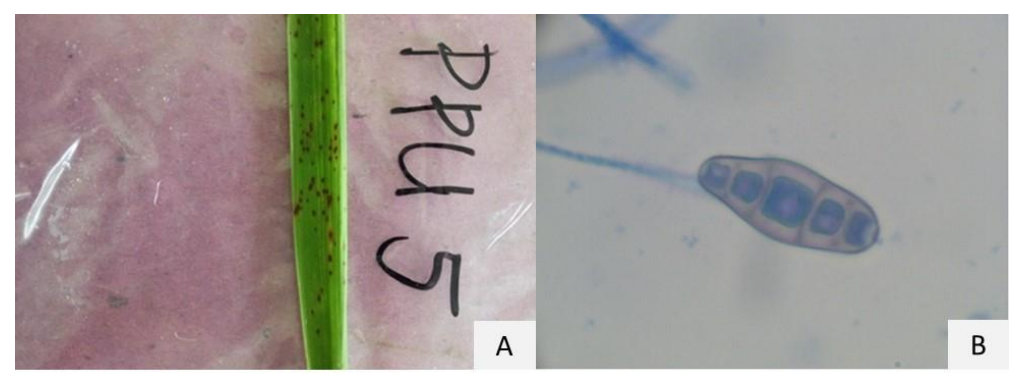

Fig 3. Brown Spot disease; A. The infected leave; B. Conidia of Helminthosporium oryzae.

Table 4. Number of resistant genotypes against particular rice disease.

\begin{tabular}{lllll}
\hline \multirow{2}{*}{ Disease } & \multicolumn{2}{l}{ Number of cultivar } & \multirow{2}{*}{ Total } & \multirow{2}{*}{$\%$} \\
\cline { 2 - 3 } & $\mathrm{X}^{*}$ & $\mathrm{Y}^{*}$ & & \\
\hline Bacterial Blight & 15 & 11 & 26 & 23.9 \\
Narrow Brown Spot & 32 & 10 & 42 & 38.5 \\
Brown Spot & 56 & 19 & 75 & 68.8 \\
Sheath Blight & 91 & 2 & 93 & 85.3 \\
\hline
\end{tabular}

$\left(X^{*}\right)$ No disease infection either in screen house condition or field trial; $\left(Y^{*}\right)$ No disease infection in the screen house, but infected in field trial with maximal intensity $5 \%$.

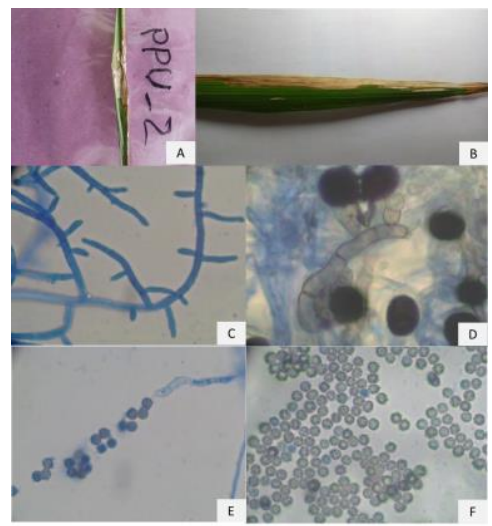

Fig 4. Sheath blight disease; A-B. The infected leaves; C. Hyfa of Rhizoctonia solani; D. Sporangium of Rhizoctonia solani; E-F. Spora of Rhizoctonia solani.

Table 5. East and North Kalimantan local upland cultivars having broad-spectrum resistance against rice diseases.

\begin{tabular}{|c|c|c|c|c|c|c|c|}
\hline \multirow{2}{*}{ No. } & \multirow{2}{*}{ Number of cultivar } & \multirow{2}{*}{ Origin } & \multirow{2}{*}{ Rice type } & \multicolumn{4}{|c|}{ Disease intensity (\%) } \\
\hline & & & & $\mathrm{BB}^{*}$ & NBS & BS & SB \\
\hline 1. & Ketan Tangkai Ngeno' & Paser & Glutinous & - & - & 3 & - \\
\hline 2. & Ketan Hitam & Penajam Paser Utara & Glutinous & 5 & - & - & - \\
\hline 3. & Ketan Gunung & Penajam Paser Utara & Glutinous & 5 & 5 & - & - \\
\hline 4. & Sereh & Penajam Paser Utara & Non-glutinous & 5 & 5 & - & - \\
\hline 5. & Geragai & Paser & Non-glutinous & 5 & 5 & - & - \\
\hline 6. & Arum & Kutai Barat & Non-glutinous & 5 & - & 2 & - \\
\hline 7. & Kalung bitik & Kutai Barat & Non-glutinous & 5 & - & - & - \\
\hline 8. & Plai Muq Sie & Kutai Timur & Non-glutinous & 5 & - & - & - \\
\hline
\end{tabular}

"Bacterial Blight (BB), Brown Spot (BS), Sheath Blight (SB), Narrow Brown Spot (NBS). 


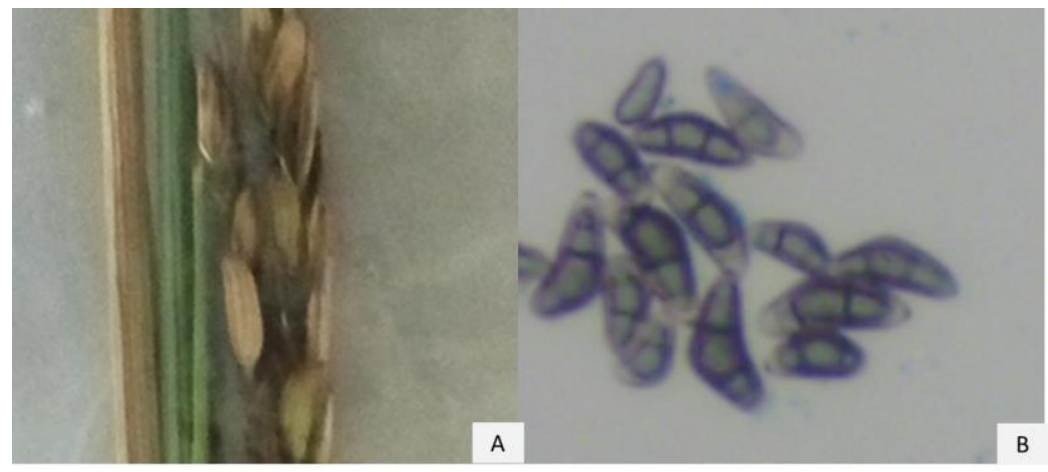

Fig 5. Black Kernel disease; A. The infected grains; B. Conidia of Curvularia lunata.

Table 6. East and North Kalimantan local upland rice cultivars used as plant materials.

\begin{tabular}{lcll}
\hline \multirow{2}{*}{ District $^{*}$} & \multirow{2}{*}{ Number of Cultivar } & Rice type & \\
\cline { 3 - 4 } & & Glutinous rice & Non-glutinous rice \\
\hline Penajam Paser Utara (E) & 8 & 3 & 5 \\
Paser (E) & 17 & 6 & 11 \\
Kutai Barat (E) & 40 & 4 & 36 \\
Kutai Kartanegara (E) & 12 & 2 & 10 \\
Kutai Timur (E) & 9 & 0 & 9 \\
Berau (E) & 7 & 3 & 4 \\
Bulungan (N) & 5 & 0 & 5 \\
Nunukan (N) & 11 & 1 & 10 \\
\hline Total & 109 & 19 & 90 \\
\hline
\end{tabular}

"(E) East Kalimantan; (N) North Kalimantan.

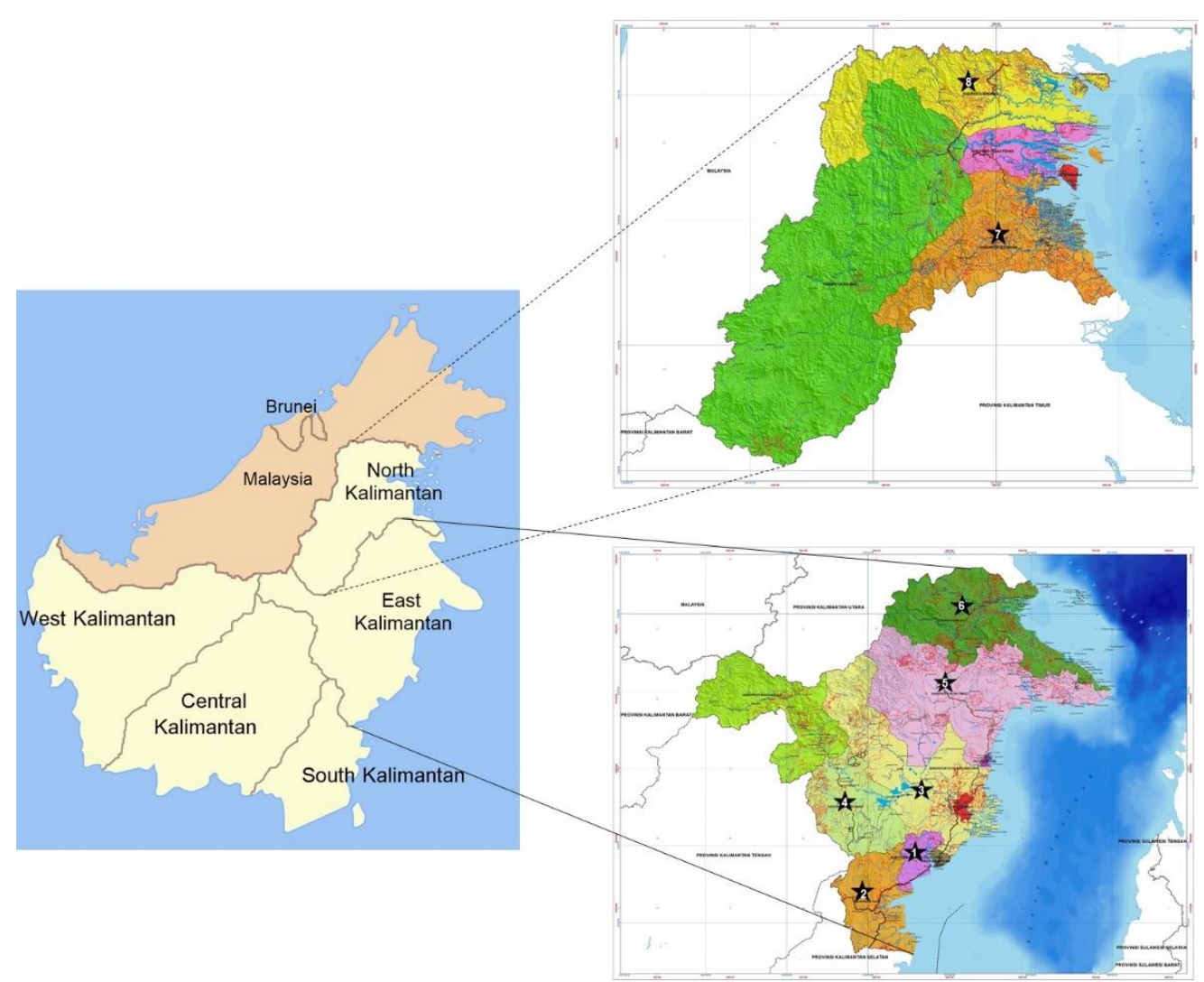

Fig 6. The origin of plant materials, East Kalimantan Province: (1) Penajam Paser Utara, (2) Paser, 3) Kutai Kartanegara, 4) Kutai Barat, 5) Kutai Timur, 6) Berau; North Kalimantan Province: 7) Bulungan, 8) Nunukan. 
resistant, moderately susceptible and susceptible (IRRI, 2002; Manandhar et al. 2016). Most of the local rice cultivars were included into resistant and moderate resistant, and only a few cultivars were grouped into susceptible and moderately susceptible (Table 2).

\section{Disease susceptibility and resistance}

The response of East and North Kalimantan local upland rice cultivars against the rice diseases were varied. Several cultivars were resistant to particular disease but susceptible to others. Most of the cultivars were infected by only one or two types of diseases either in screen house or field trial growing condition (Table 3 ). On the other hand, there were cultivars infected by three to four diseases at the same time. From 109 local upland rice cultivars examined in this study, four genotypes (3.7\%) were categorized as the most vulnerable cultivars in screen house condition, which could be infected by three diseases. Unfortunately, this number considerably increased in the field trial condition. Eight genotypes which were infected by one disease only in the screen house could be infected by three to four diseases in the field experiment condition.

In this study, twenty to eighty percent of local upland rice cultivars were resistant to rice diseases (Table 4), with no disease infection, neither in screen house condition nor field trial; or have no disease infection in screen house but infected by the disease with the maximal intensity of five percent. Among all rice diseases, bacterial blight was the most widespread disease in the local rice population, and only twenty percent of the local upland rice genotypes were resistant to this disease. In another situation, around eighty percent of East and North Kalimantan local upland rice population were observed resistant against sheath blight disease. From all resistant genotypes, we extracted eight genotypes which were resistant to all rice diseases, i.e., bacterial blight, narrow brown spot, brown spot, and sheath blight, infecting the local rice population (Table 5).

\section{Discussion}

Several rice diseases were caused by bacteria and fungi on East and North Kalimantan local upland rice population. Among all, bacterial blight caused by bacteria Xanthomonas oryzae was recognized as the most frequent disease infecting the plants, either in the screen house or field trial (Table 1). Bacterial blight is a serious rice disease and becomes a major constraint for rice production, not only in Asia but also in all rice-growing regions of the world (Mew, 1987; Niño-Liu et al. 2006). In this study, the local rice population was grown following upland rice growing condition, and this disease could spread widely and infect almost fifty and eighty percent of the local rice cultivars in the screen house and field trial, respectively. It indicated that bacterial blight is a boundless spread rice disease, infecting not only in a wetland but also in dryland growing condition.

A highly destructive disease, blast was not present in the studied populations. We observed neither the symptoms nor causing agents in the both of cultivation areas. The disease was not present in the neighborhood of rice planting area. It is concluded that rice blast has not been spread in the research sites yet. Based on several reports, blast disease has been spotted only in a few places in East Kalimantan. In addition, rice blast is favored by moderate temperatures and high moisture (Bonman, 1992; Hodson and White 2010), in which generally attainable in irrigated or flooded rice fields. The impacts of blast are greater in cooler rice producing regions. The growing condition of upland rice and the local climate might not support for the spreading of this disease in the current research region.

Rice diseases infected the local rice population with different frequency and intensity. Sheath blight was observed as the narrow spread disease compared to others, infecting the local rice cultivars at the rarest frequency and the lowest intensity. Disease pathogens infected the rice population unequally at the same time. Large differences in disease severity are often found in the adjacent plant, even if all individual response to the pathogen identically (Burdon, 1987). Each disease differs in their dispersal ability influencing by the pathogen genotype, host genotype, and the spatial configuration of the host plant (Tack et al., 2014). Different frequency and intensity of the diseases in this study might be due to the different dispersal ability of the disease pathogens; and/or related to the plant immune system, a defense mechanism of resistance genotype to limit the development of related pathogen (Ellis and Jones 2003; Dodds and Rathjen, 2010).

Remarkably, a specific interaction between the host and pathogen was observed in this study. Some genotypes are resistant and others are susceptible to the particular disease (Table 2-4). There is a host-pathogen interaction, meaning that particular pathogen compatible with certain plant genotype. Each plant genotype secretes specific metabolite, which serves as signals for the pathogen to further like or dislike the plant (Giraldo and Valent 2013; Yi and Valent 2013; Zeilinger et al., 2016). The pathogen can distinguish the susceptible or resistant host genotype. Correspondingly, the resistant plant genotypes have developed effective mechanisms to recognize and respond to infections caused by pathogens, by suppressing the growth or replication of pathogen at the site of the infection completely or partially (Ellis and Jones 2003). The pathogen was unable to infect the resistant genotypes, in which no disease symptom was observed in the plant as a complete suppression mechanism. In another situation, the symptoms were present, but they did not further develop, which might be observed as very low disease intensity.

Plants will be resistant to the pathogens when the plant carries a corresponding resistance gene. There are two types of resistance in plant disease resistance mechanism, race specific, also called as qualitative resistance, and race nonspecific or quantitative plant resistance (Dang and Jones, 2001; Fu et al. 2011; Sekhwal et al. 2015). The qualitative (vertical) resistance is a narrow-spectrum resistance mediated by a single or a few major genes that operate in a gene-for-gene fashion (Flor, 1971; Van der Biezen and Jones, 1998; Ohtsuki and Sasaki, 2006). The quantitative (horizontal) resistance is a broad-spectrum resistance refers to resistance against two or more types of pathogens, contributed by multiple genes or quantitative trait loci (QTLs) (Kou and Wang, 2010; Burdon et al. 2014). In this study, the two type of resistance might present in the local upland rice population, represented by the resistant plant genotypes against particular disease (Table 5), and resistant plant genotypes against several diseases (Table 6), indicating the existence of vertical and horizontal resistance, respectively. 


\section{Materials and Methods}

\section{Plant materials}

A total of 109 local upland rice cultivars, consist of 19 glutinous and 90 non-glutinous rice genotypes were used as plant material in this study (Table 6). The local upland rice cultivars were collected from eight districts in East and North Kalimantan, namely Penajam Paser Utara, Paser, Kutai Kartanegara, Kutai Barat, Kutai Timur, Berau, Bulungan and Nunukan (Figure 6).

\section{Field trials}

The local upland rice cultivars were grown in two different growing conditions, in screen house and in the field, to evaluate their response against diseases. Plant disease resistance was evaluated using natural disease epidemic selection (Russel, 1978), in which the plants were grown in a disease endemic media and location. In screen house condition, the cultivars were grown in perforated plastic pots containing diseases infected soil. The pots were filled with 10 $\mathrm{kg}$ of potting mix comprising of compost and soil at a ratio of 1:1 (v/v). The seeds were directly sown in planting media without transplanting, and only one good growing plant was maintained.

At the same time, the seeds were also grown in the field to check resistance parallelism at different growing condition. The field experiment took place in a rice disease endemic location, where rice diseases were present in previous growing season, in which representative as natural field epidemic for rice diseases. Prior to sowing, conventional soil tillage was applied in plots $(2 \mathrm{~m} \times 3 \mathrm{~m})$ forming as beds. The seeds were directly sown in planting holes of $25 \mathrm{~cm} \times 30 \mathrm{~cm}$ distances, in the field experiment condition. The plants were grown and maintained according to general rice cultivation procedure for both of growing condition, in the screen house and the field experiment.

\section{Disease observation and characterization}

Disease observation was conducted when the rice plants were at grain filling to harvest stage. Diseases were characterized by their symptoms on the plants. Disease intensity was scored by observing the percentage of disease symptoms on the plants in the field trial. The percentage of infected area was rated from the lesions length and number of lesions on the plants. Disease scale and scoring method, as well as disease severity were analyzed based on IRRI (2002) and Manandhar et al. (2016).

The infected part of the plants was inoculated in Potato Dextrose Agar (PDA) media to further analyze the disease causing agents. Prior to inoculation, the infected part of the plants $\left( \pm 1 \mathrm{~cm}^{2}\right)$ was sterilized using alcohol $70 \%$ solution for 1 minute, rinsed with sterilized distilled water and dried in sterilized tissue. The sterilized explants then were inoculated in PDA growing media and incubated for three days in $\pm 25^{\circ} \mathrm{C}$ room temperature. The sterilization and inoculation processes were performed in a Laminar Air Flow Cabinet (LAFC).

The inoculum was observed under a light microscope to characterize the diseases causing agents. Coloring agent lactophenol was used to clearly observe the fungi. Fungi identification was performed based on Barnett and Hunter (1998). For bacteria identification, gram staining was carried out to characterize the bacteria as gram-positive or gramnegative, based on the chemical and physical properties of their cell walls (Hucker, 1921). Gram-positive bacteria appear purple, due to the crystal violet trapped within their thick cell walls. On the other hand, a pink color will appear for gramnegative bacteria, since the violet washed through the thin cell walls, then the pink counterstain entered them.

\section{Conclusion}

Genetic resistance is the best strategy that has long been the mainstay of agricultural crop production. There are no effective ways of protecting rice from diseases other than by development of resistant cultivars. The putative resistance genotypes in the East Kalimantan local upland rice population, characterized in this study, might contain genes that confer resistance to one or more pathogens, which could be further used as the source of vertical or horizontal resistance genes in rice breeding programs.

\section{Acknowledgements}

This study was funded by PUPT Grant 2016-2017 Ministry of Research, Technology and Higher Education of the Republic of Indonesia to which the authors are highly indebted.

\section{References}

Agrios GN 2005. Plant Pathology ( $5^{\text {th }}$ edition). San Diego CA: Elsevier-Academic Press: 952.

Anderson PK, Cunningham AA, Patel NG, Morales FJ, Epstein PR, Daszak P (2004) Emerging infectious diseases of plants: pathogen pollution climate change and agrotechnology drivers. Trends Ecol Evol. 19: 535-544.

Barnett HL, Hunter BB (1998) Illustrated Genera of Imperfect Fungi $4^{\text {th }}$ edition. Minnesota: APS Press St Paul.

Barnwal MK, Kotasthane A, Magculia N, Mukherjee PK, Savary S, Sharma AK, Singh HB, Singh US, Sparks AH, Variar M, Zaidi N (2013) A review on crop losses epidemiology and disease management of rice brown spot to identify research priorities and knowledge gaps. Eur J Plant Pathol. 136(3): 443-457.

Bhaktavatsalam G, Satyanarayana K, Reddy PK, John VT (1978) Evaluation of sheath blight resistance in rice. Int Rice Res Newsletter. 3: 9-10.

Bonman JM (1992) Rice Blast. In: Webster R K, Gunnel P S. Compendium of Rice Diseases. St. Paul Minnesota, USA: American Phytopathological Society Press: 14-18.

Breckenridge C, Sangerapillai V (1978) Study of the incidence of 'black grain' in rice and its effect on quality. Trop Agriculturist. 134: 43-53.

Burdon JJ (1987) Disease and Plant Population Biology. New York, USA: Cambridge University Press.

Burdon JJ, Barrett LG, Rebetzke G, Thrall PH (2014) Guiding deployment of resistance in cereals using evolutionary principles. Evol Appl, 7: 609-624.

Cabi (2017) http://www cabi org/isc/datasheet/17046. Accessed: 12062017.

Dang JL, Jones JD (2001) Plant pathogens and integrated defence responses to infection. Nature. 411: 826-833. 
Dodds PN, Rathjen JP (2010) Plant immunity: towards an integrated view of plant-pathogen interactions. Nat Rev Genet. 11(8): 539-548.

Ellis JG, Jones DA (2003) Plant disease resistance genes. In: Ezekowitz R A B, Hoffmann J A. Infectious Disease: Innate Immunity. Totowa, New Jersey: (C) Humana Press Inc.: 2745.

Eskenazi B, Bradman A, Castorina R (1999) Exposures of children to organophosphate pesticides and their potential adverse health effects. Environ Health Perspect. 107(3): 409-419.

Flor HH (1971) Current status of the gene-for-gene concept. Annu Rev Phytopathol. 9: 275-296.

Fu J, Liu H, Li Y, Yu H, Li X, Xiao J, Wang S (2011) Manipulating broad-spectrum disease resistance by suppressing pathogen-induced auxin accumulation in rice. Plant Physiol. 155: 589-602.

Geigera F, Bengtssonb J, Berendsea F, Weisserc WW, Emmersond $\mathrm{M}$, Moralesf $\mathrm{MB}$, Ceryngierg $\mathrm{P}$, Liirah J, Tscharntkei T, Winqvistb C, Eggersb $S$, Bommarcob R, Pärtb $T$, Bretagnollej V, Plantegenestk $M$, Clementc $L W$, Dennisd C, Palmerd C, Oñatef JJ, Guerrerof I, Hawrog V, Aavikh T, Thiesi C, Flohrei A, Hänkei S, Fischeri C, Goedhart PW, Inchaustij P (2010) Persistent negative effects of pesticides on biodiversity and biological control potential on European farmland. Basic Appl Ecol. 11(2): 97105.

Giraldo MC, Valent B (2013) Filamentous plant pathogen effectors in action. Nat Rev Microbiol. 11: 800-814.

González-Rodríguez RM, Rial-Otero R, Cancho-Grande B, Simal-Gándara J, Rial-Otero R (2008) Occurrence of fungicide and insecticide residues in trade samples of leafy vegetables. Food Chem. 107(3): 1342-1347.

Hodson D, White J (2010) GIS and crop simulation modelling applications in Climate Change Research. In: Reynolds M P. Climate Change and Crop Production. London, UK: CAB International: 245-262.

Hucker G J (1921) A new modification and application of the gram stain. J Bacteriol. 6: 395-397.

Hura C, Leanca M, Rusu L, Hura BA (2008) Risk assessment of pollution with pesticides in food in the Eastern Romania area (1996-1997). Toxicol Lett. 107: 103-107.

IRRI (2002) Standard Evaluation System for Rice. Los Banos Manila, Philippines: International Rice Research Institute.

Kihoro J, Bosco NJ, Murage H, Ateka E, Makihara D (2013) Investigating the impact of rice blast disease on the livelihood of the local farmers in greater Mwea region of Kenya. Springerplus. 2(308): 1-13.

Khush GS, Virmani SS (1985) Breeding rice for disease resistance. In: Russel G E. Progress in Plant Breeding. Butterworth-Heinemann: Butterworth Co Publishers Ltd: 239-280.

Kou Y, Wang S (2010) Broad-spectrum and durability: understanding of quantitative disease resistance. Curr Opin Plant Biol. 13: 181-185.

Manandhar HK, Timila RD, Sharma S, Joshi S, Manandhar S, Gurung SB, Sthapit S, Palikhey E, Pandey A, Joshi B, Manandhar G, Gauchan D, Jarvis D I, Sthapit BR (2016) A field guide for identification and scoring methods of diseases in the mountain crops of Nepal. Pokhara, Nepal: Bioversity International.
Mew TW (1987) Current status and future prospects of research on bacterial blight of rice. Annual Rev Phytopathol. 25: 359-382.

Mills $P$, Dehnen-Schmutz K, Ilbery B, Jeger $M$, Jones $G$, Little R, MacLeod A, Parker S, Pautasso M, Pietravalle S, Maye D (2011) Integrating natural and social science perspectives on plant disease risk management and policy formulation. Phil Trans R Soc B. 366: 2035-2044.

Niño-Liu DO, Ronald PC, Bogdanove AJ (2006) Xanthomonas oryzae pathovars: Model pathogens of a model crop. Mol Plant Pathol. 7: 303-324.

Nurhasanah, Sadaruddin, Sunaryo W (2016) Diversity analysis and genetic potency identification of local rice cultivars in Penajam Paser Utara and Paser Districts East Kalimantan. Biodiversitas. 17(2): 401-408.

Nurhasanah, Sadaruddin, Sunaryo W (2017) Yield-related traits characterization of local upland rice cultivars originated from East and North Kalimantan Indonesia. Biodiversitas. 18(3): 1165-1172.

Ohtsuki A, Sasaki A (2006) Epidemiology and disease-control under gene-for-gene plant-pathogen interaction. J Theor Biol. 238: 780-794.

Paoletti MG, Pimentel DS (2000) Environmental risks of pesticides versus genetic engineering for agricultural pest control. J Agric Envir Ethics. 12: 279-303.

Pautasso M, Döring TF, Garbelotto $M$, Pellis L, Jeger MJ (2012) Impacts of climate change on plant diseasesopinions and trends. Eur J Plant Pathol. 133: 295-313.

Pennisi E (2010) Armed and dangerous. Science. 327: 804805.

Prasad B, Eizenga GC (2008) Rice sheath blight disease resistance identified in Oryza spp accessions. Plant Dis. 92: 1503-1509.

Russel GE (1978) Plant breeding for pest and disease resistance: Studies in the agricultural and food sciences. Butterworth-Heinemann: Butterworth Co Publishers Ltd

Savary S, Ficke A, Aubertot J-N, Hollier C (2012) Crop losses due to diseases and their implications for global food production losses and food security. Food Sec. 4: 519-537.

Sekhwal M K, Li P, Lam I, Wang X, Cloutier S, You FM (2015) Disease resistance gene analogs (RGAs) in plants. Int J Mol Sci. 16(8): 19248-19290.

Sparks A, Nelson A, Castilla N (2012) Where rice pests and diseases do the most damage. Rice Today. 11(4): 26-27.

Subramanian CV, Jain BL (1966) A revision of some graminicolous Helminthosporia. Current Science. 35: 352355.

Sunder S, Singh R, Agarwal R (2014) Brown spot of rice: an overview. Indian Phytopathol. 67(3): 201-215.

Swings J, Mooter MVD, Vauterin L, Hoste B, Gillis M, Mew T W, Kersteres K (1990) Reclassification of the causal agents of bacterial blight (Xanthomonas campestris pv. oryzicola) of rice as pathovars of Xanthomonas oryzae (ex Ishiyama 1922) sp. nov nom rev. Int J Sys Evol Micr. 40: 309-311.

Tack AJM, Hakala J, Petãjã T, Kulmala M, Laine A-L (2014) Genotype and spatial structure shape pathogen dispersal and disease dynamics at small spatial scales. Ecology. 95(3): 703-714.

Teng PS (1990) Integrated pest management in rice: an analysis of status quo with recommendation for action Project report submitted to the multiagency. Integrated Pest Manage Task Force. 2: 79-84. 
Van der Biezen EA, Jones JD (1998) Plant disease-resistance proteins and the gene-for-gene concept. Trends Biochem Sci. 23: 454-456.

Yi M, Valent B (2013) Communication between filamentous pathogens and plants at the biotrophic interface. Annu Rev Phytopathol. 51: 567-611.
Zadoks JC (2008) On the political economy of plant disease epidemics capita selecta in historical epidemiology. Wageningen: Wageningen Academic Publishers.

Zeilinger S, Gupta VK, Dahms TES, Silva RN, Singh HB, Upadhyay RS, Gomes EV, Tsui CK-M, Nayak SC (2016) Friends or foes? Emerging insights from fungal interactions with plants. FEMS Microbiol Rev. 40(2): 182-207. 